\title{
БАЛЬНА ОЦІНКА ТЯЖКОСТІ СТАНУ ХВОРИХ НА ЦУКРОВИЙ ДІАБЕТ, УСКЛАДНЕНИЙ НЕКРОТИЧНО-ЗАПАЛЬНИМ УРАЖЕННЯМ СТОПИ, ПРИ ПОВТОРНИХ ОПЕРАЦІЯХ НА НИЖНІХ КІНЦІВКАХ
}

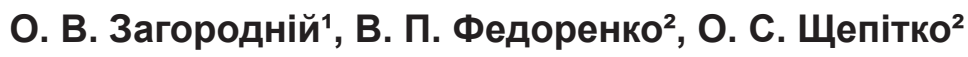

1 Львівський обласна клінічна лікарня,

${ }^{2}$ Львівський національний медичний університет імені Данила Галицького

\section{ASSESSSMENT OF SEVERITY STATE OF THE PATIENTS BY DIABETES MELLITUS, COMPLICATED WITH NECROTIC-INFLAMMATORY LESIONS OF THE FOOT AT THE SURFACE OF OPERATION AT LOWER EXTREMITIES}

\author{
O. V. Zahorodniy', V. P. Fedorenko², O. S. Shchepitko² \\ ${ }^{1}$ Lviv Regional Clinical Hospital, \\ ${ }^{2}$ Lviv National Medical University named after Danylo Halytsky
}

\begin{abstract}
Рефрерат
Вступ. У хворих на цукровий діабет (ЦД), ускладнений некротично-запальним ураженням стопи (НЗУС), складна анатомічна будова стопи в поєднанні з тяжким некротично-гнійним процесом без чітких меж ураження не дозволяє досягти радикальності хірургічної санації під час одного хірургічного втручання, тому лікування часто має бути багатоетапним.

Матеріали і методи. Здійснена бальна оцінка тяжкості стану 106 хворих на ЦД, ускладнений НЗУС, перед високою ампутацією (BA) нижньої кінцівки (НК), як першим, другим та подальшими втручаннями.

Результати. Встановлено, що стан хворих погіршувався, залежно від етапу, на якому виконували ВАНК.

Обговорення. Показання до виконання ВАНК слід встановлювати одразу, а не після численних повторних втручань на стопі на тлі прогресуючого погіршення стану хворого.

Висновок. Опрацьована класифікація НЗУС у хворих на ЦД, застосування бальної оцінки тяжкості стану хворих за модифрікованою системою АРACHE II дозволило визначити прогноз і обґрунтувати тактику лікування.

Ключові слова: цукровий діабет; ускладнення; некротично-запальне ураження стопи; хірургічне лікування.

Abstract

Introduction. In the patients with diabetes mellitus (DM), the complicated anatomical structure of the foot in combination with severe necrotic-purulent process without clear limits of defect does not allow to achieve the radicals of surgical sanation during one surgical intervention, and therefore it often has a multi-stage.

Materials and methods. The ball assessment of the severity state of 106 patients with DM, complicated by necrotic-inflammatory lesions of the foot was performed before high amputation of the lower limb, as the first, second, third or subsequent operations.

Results. It was established that the state of the patients worsened, depending on which stage performed a high amputation of the lower limb.

Discussion. Indications for performing a high amputation of the lower limb should be determined immediately, but not after numerous repeated operations on the foot, against the background of a progressive deterioration of the patient's state.

Conclusion. The treated classification of necrotic-inflammatory lesions of the foot in patients with DM, application of a ballroom assessment of the state severity of patients with the modified APACHE II system, allows to determine the prognosis and justify treatment tactics.

Keywords: diabetes mellitus; complication; necrotic-inflammatory lesion of foot; surgical treatment.
\end{abstract}

Виникнення хірургічних ускладнень - НЗУС у хворих на Цд свідчить про пізні стадії та ускладнений перебіг захворювання, загрозу формування «хибного кола» взаємообтяження, за якого, внаслідок метаболічних, гемореологічних розладів, ішемії тканин, гнійної інтоксикації, сепсису, синдрому системної запальної відповіді (ССЗВ) можуть з'явитися гостра серцево-судинна недостатність, інфаркт міокарда, порушення кровообігу головного моз- ку, тромбоемболія легеневої артерії, ниркова недостатність, що є безпосередньою причиною смерті хворих $[1-7]$.

3 метою розриву «хибного кола», насамперед, для збереження життя хворого немає альтернативи адекватному хірургічному втручанню, зокрема, реваскуляризації НК, а за протипоказань до неї - ВАНК.

За збереженого кровопостачання НК - нейропатично-інфікованої форми синдрому діабетичної стопи
(СДС) ВАНК виконують в 1,2\% хворих, змішаної - у 2,6\%, при порушенні кровопостачання НК - ішемічногангренозній формі - у 34,7\% [2]. 3 приводу панфлегмони, міонекрозу, остеомієліту, стопи Шарко ВАНК виконують в 11,1\% хворих, акрального некрозу, гангрени пальців, стопи, гомілки - у 35,8\% [8]. При сепсисі (ССЗВ) ВАНК виконують у 59,1\% [7] 87,6\% [6] хворих.

Складна анатомічна будова стопи в поєднанні з тяжким некротично- 
гнійним процесом без чітких меж ураження не дозволяє досягти радикальності хірургічної санації під час одного хірургічного втручання, тому лікування часто має бути багатоетапним [9, 10]. Деякі автори стверджують, що виконання численних повторних парціальних втручань на стопі може зменшити частоту ВАНК [7, 8, 11]. Проте, за тривалого існування рани у хворого на џД, навіть після ії ретельної механічної й хімічної санації, можливе поширення процесу по сухожильно-фасціальних структурах з подальшою генералізацією інфекції, виникненням сепсису на тлі, здавалося б, сприятливого перебігу захворювання [12].

Мета дослідження: бальна оцінка тяжкості стану хворих на Цд, ускладнений НЗУС, після повторних операцій на НК.

\section{МАТЕРІАЛИ I МЕТОДИ ДОСЛІДЖЕННЯ}

Проаналізовані результати хірургічного лікування 168 хворих на ЦД (22 - тип I, 146 - тип II), ускладнений НЗУС, госпіталізованих у відділення загальної (119) і судинної (49) хірургії, яким здійснені 256 операцій на НК за період 2003 - 2014 рр. Крім НЗУС, ретинопатія діагностована у $14,6 \%$, нефропатія - у 71,2\%, анемія у $36,4 \%$, ішемічна хвороба серця - у 28,4\%, інфаркт міокарда - у 7,7\%, інсульт головного мозку - у 3,5\%, ознаки сепсису (ССЗВ) - у 8,2\% хворих.

При побудові діагнозу, визначенні прогнозу та плануванні лікування використовували такі класифікаційні критерії: 1) тяжкість ішемії тканин НК; 2) локалізація та поширення НЗУС (дистальна чи проксимальна частина стопи, вся стопа, гомілка); 3) ступінь деструкції (поверхневі вогнища некрозу, виразки на пальцях і стопі, глибокі виразки з поши- ренням на сухожилля, кістки); 4) характер запальної реакції (сухий некроз, флегмона, абсцес стопи); 5) особливості мікрофлори; 6) ознаки сепсису (СС3В); 7) гіпохромна анемія, зумовлена діабетичною нефропатією, сепсисом (ССЗВ) або повторними хірургічними втручаннями; 8) інші ускладнення ЦД та супутні захворювання [13].

У хворих на ЦД, ускладнений НЗУС, система АРАСНЕ II в нашій модифікації доповнена бальною оцінкою тяжкості ураження стопи за F. W. Wagner, визначенням показників глікеміі, імунітету (паличкоядерні лейкоцити, лімфоцити), анемії (еритроцити, гемоглобін), запалення (ШОЕ, фібриноген), обсягу хірургічного втручання (некректомія, розкриття флегмони, ампутація НК на рівні пальців, стопи, гомілки, стегна, реваскуляризація НК). Отримані абсолютні показники загальноклінічного, лабораторного, біохімічного дослідження та хірургічного втручання конвертували у бали. Показники, що перебували в межах норми, або якщо їх не визначали, оцінювали 0 балів, решту - залежно від ступеня відхилення [13].

Статистичні показники опрацьовано 3 допомогою спеціалізованої програми «Медична статистика» за загальноприйнятими методами. Вірогідність (р) встановлювали за t-критерієм Стюдента, результати оцінювали як вірогідні при р <0,05.

\section{РЕЗУЛЬТАТИ}

Для порівняльного аналізу тяжкості стану хворих на Цд, ускладнений НЗУС, при повторних операціях на НК за модифікованою системою AРАCHЕ II виділені три групи. У 62 хворих (1-ша група) здійснене стандартне лікування без ВАНК (3 них 2 померли), у 106 хворих (2-га група) - проведене стандартне лікування з ВАНК (15 померли); у 6 хворих (3-тя група) - виконана повторна ампутація після ВАНК (1 помер). Результати бальної оцінки тяжкості стану хворих на џд, ускладнений НЗУС, при повторних операціях на НК за модифікованою системою APACHЕ II наведені у таблиці.

\section{ОБГОВОРЕННЯ}

У хворих 1-ї групи кількість балів перед першою операцією достовірно не відрізнялася від такої перед другою, третьою або подальшими операціями ( $p>0,05)$, проте, була достовірно меншою, ніж у хворих 2-і групи перед другою ( $<<0,05)$, третьою або подальшими операціями $(\mathrm{p}<0,001)$. Кількість балів у 2 хворих 1-ї групи та 15 - 2-ї групи, які померли, була достовірно більшою, ніж у хворих 1-ї групи після повторних операцій, та у хворих, яким здійснено ВАНК першим або другим втручанням $(\mathrm{p}<0,001)$. Також відзначене погіршення стану хворих 3-ї групи після ВАНК: в одного - 40,0 балів, у 5 - $(46,6 \pm 6,2)$ бала, в одного померлого - 51,0 бал.

Отже, показання до виконання ВАНК треба визначати одразу, а не після численних повторних втручань на стопі, на тлі прогресуючого погіршення стану хворого.

Через уповільнення загоєння операційних ран на стопі у хворих на ЦД критеріями для виписування хворих є припинення поширення гнійно-некротичного процесу, поява в операційній рані грануляційної тканини, початок крайової епітелізації [3]. Часто цього недостатньо, про що свідчить повторна госпіталізація хворих у найближчі 2 тиж [14].

Нажаль, після виписування 3 хірургічного стаціонару у 136 (73\%) хворих операційні рани на стопі за-

Результати бальної оцінки тяжкості стану хворих на ЦД, ускладнений НзУС, при повторних операціях на НК за модифікованою системою АРАCHE II

\begin{tabular}{|c|c|c|c|c|c|c|c|c|c|}
\hline \multirow{3}{*}{ Період спостереження } & \multicolumn{9}{|c|}{ Величина показника в групах } \\
\hline & \multicolumn{3}{|c|}{ 1-й } & \multicolumn{3}{|c|}{$2-и ̆$} & \multicolumn{3}{|c|}{$3-и ̆$} \\
\hline & 1 & 2 & 3 & 1 & 2 & 3 & 1 & 2 & 3 \\
\hline $\begin{array}{l}\text { Після госпіталізації або перед } \\
\text { першою ВАНК }\end{array}$ & 62 & - & $31,4 \pm 0,9$ & 64 & 64 & $31,4 \pm 0,9$ & - & - & - \\
\hline Перед другою операцією & 38 & 38 & $31,9 \pm 0,9$ & 20 & 20 & $35,3 \pm 1,3$ & 1 & 1 & 40,0 \\
\hline $\begin{array}{l}\text { Перед третьою та подальшими } \\
\text { операціями }\end{array}$ & 24 & 56 & $32,8 \pm 0,9$ & 22 & 66 & $43,0 \pm 1,7$ & 5 & 11 & $46,6 \pm 6,2$ \\
\hline Померли & 2 & 4 & $41,5 \pm 0,8$ & 15 & 22 & $40,8 \pm 1,0$ & 1 & 3 & 51,0 \\
\hline
\end{tabular}

Примітка.

1 - кількість хворих; 2 - кількість операцій; 3 - кількість балів ( $\bar{x} \pm$ m). 
гоювались протягом (93 \pm 10$)$ діб [3]. Комплексне лікування ран при нейроішемічній формі СДС, що включало використання вакуум-терапії на різних етапах ранового процесу, дозволило досягти повного загоєння ранового дефекту у 33 (66\%) пацієнтів протягом $(62,5 \pm 2,7)$ доби, ВАНК на рівні середньої трети-

\section{REFERENCES}

1. Herasymov HM. Khirurhichna taktyka i sposoby operatyvnoho likuvannia uskladnenoho syndromu diabetychnoi stopy. Mizhnarodnyi medychnyi zhurnal. 2015;21(3):13-5. [In Ukrainian].

2. Herasymchuk PO, Vlasenko VH, Pavlyshyn AV. Sepsys u khvorykh na uskladneni formy syndromu diabetychnoi stopy. Scientific Journal "ScienceRise". 2015;11.3(16):30-3. [In Ukrainian].

3. Zheliba MD, Burkovskyi MI, Tsariuk YuS, Verba AV. Bezposeredni i viddaleni rezultaty likuvannia hniino-nekrotychnykh protsesiv syndromu stopy diabetyka. Ukrainskyi Zhurnal Khirurhii. 2009;4:55-9. [In Ukrainian].

4. Marchenko OV. Shliakhy korektsii modyfikovanykh faktoriv ryzyku v likuvanni syndromu diabetychnoi stopy. Mizhnarodnyi endokrynolohichnyi zhurnal. 2015;5:110-5. [In Ukrainian].

5. Palamarchuk VI, Markov KV, Siriachenko VH. Likuvannia syndromu diabetychnoi stopy $v$ umovakh viddilennia hniino-septychnoi khirurhii. Klinichna Khirurhiia. 2011;(11):37-8. [In Ukrainian].

6. Tamm TI, Belov SG, Girka Jel, Solovej AN, Glushhenko JaA. Osobennosti diagnostiki i lechenija bol'nyh po povodu sindroma diabeticheskoj stopy, oslozhnennogo sepsisom. Klinichna Khirurhiia. 2011;(11):33-4. [In Russian].

7. Trybushnoi OV, Shapoval SD, Savon IL, Slobodchenko LYu. Mikrobnyi peizazh hniinykh oseredkiv u khvorykh z uskladnenym syndromom diabetychnoi stopy ta pry rozvytku sepsysu. Ukrainskyi Zhurnal Khirurhii. 2017;1(32):35-9. [In Ukrainian].

8. Shapoval SD, Savon IL, Smyrnov DA, Sofilkanich MM, Omelchenko MM, Belinskaya VO. Standarty protokoliv likuvannia uskladnenoho syndromu diabetychnoi stopy. Kharkivska khirurhichna shkola. 2013;3(60):119-23. [In Ukrainian]. рих за модифікованою системою АРАСНЕ II дозволили визначити прогноз і обгрунтувати тактику лікуванНЯ.

2. Показання до виконання ВАНК треба визначати одразу, а не після численних повторних втручань на стопі на тлі прогресуючого погіршення стану хворого.

9. Podpriatov SE. Efektyvnist povtornoho khirurhichnoho likuvannia khvorykh z diabetychnoiu stopoiu. Klinichna Khirurhiia. 2000;(5):24-5. [In Ukrainian].

10. Herych ID, Yaremkevych RV. Typovi nedoliky klasychnykh operatyvnykh vtruchan pry hniino-nekrotychnykh urazhenniakh syndromu diabetychnoi stopy (HNU SDS). Khirurhiia Ukrainy. 2005;1(13):624. [In Ukrainian].

11. Liakhovskyi VI, Krasnov OH, Liulka OM, Niemchenko II, Kravtsiv MI, Kyzymenko OO. Systemna zapalna vidpovid u khvorykh z syndromom diabetychnoi stopy. Klinichna Khirurgiia. 2015;(11.2):88. [In Ukrainian].

12. Ivashhenko VV, Ivashhenko AV. Nekotorye voprosy patogeneza, prognoza i profilaktiki sepsisa u bol'nyh s sindromom diabeticheskoj stopy. Aktualni pytannia medychnoi nauky ta praktyky. Zbirnyk naukovykh prats Zaporizkoho derzhavnoho instytutu udoskonalennia likariv. Zaporizhzhia: Dyke pole; 2003:51-6. [In Russian].

13. Fedorenko VP, Zahorodnii OV, Mota YuS. Balna otsinka stupenia vazhkosti stanu khvorykh na tsukrovyi diabet, uskladnenyi nekrotychno-zapalnymy urazhenniamy stopy, za modyfikovanoiu systemoiu APACHE II. Shpytalna khirurhiia. 2014;(2):5-8. [In Ukrainian].

14. Pysmenna NV. Struktura i chastota amputatsii nyzhnikh kintsivok $\mathrm{u}$ khirurhichnykh statsionarakh $\mathrm{m}$. Kyieva. Litopys travmatolohii ta ortopedii. 2003;(1-2):131-4. [In Ukrainian].

15. Rusyn VI, Korsak VV, Rusyn VV, Nosenko OA, Korsak luV. Kompleksne likuvannia neiroishemichnoi formy syndromu diabetychnoi stopy: mozhlyvosti vakuum-terapii. Shpytalna khirurhiia 2014;(3):51-3. [In Ukrainian]. 